\title{
Synthesis and Characterization of Symmetrically versus Unsymmetrically Proton-Bridged Hexa-Iron Clusters
}

D. Nirosha T. De Silva, Tyson N. Dais, Geoffrey B. Jameson, Daniel J. Cutler, Euan K. Brechin, Casey G. Davies, Guy N. L. Jameson, and Paul G. Plieger*

Cite This: ACS Omega 2021, 6, 16661-16669

Read Online

\section{ACCESS |}

Џlll Metrics \& More

回国 Article Recommendations

Supporting Information

ABSTRACT: Syntheses and magnetic and structural characterization of hexa-iron complexes of derivatized salicylaldoximes are discussed. Complexation of $\mathrm{Fe}\left(\mathrm{BF}_{4}\right)_{2} \cdot 6 \mathrm{H}_{2} \mathrm{O}$ with each ligand $\left(\mathrm{H}_{2} \mathbf{L} \mathbf{1}\right.$ and $\mathrm{H}_{4} \mathrm{~L} 2$ ) in a methanolic-pyridine solution resulted in hexa-iron compounds ( $\mathbf{C} 1$ and $\mathbf{C 2}$, respectively), which each contain two nearparallel metal triangles of $\left[\mathrm{Fe}_{3}-\mu_{3}-\mathrm{O}\right]$, linked by six fluoride bridges and stabilized by a hydrogen-bonded proton between the $\mu_{3}-\mathrm{O}$ groups. Within each metal triangle of $\mathbf{C 2}, \mathrm{Fe}$ (III) ions are connected via the amine "straps" of $\left(\mathrm{H}_{4} \mathbf{L} \mathbf{2}-2 \mathrm{H}\right)$. Variable-temperature magnetic susceptibility and Mössbauer data of $\mathbf{C 1}$ and $\mathrm{C2}$ indicate the presence of dominant antiferromagnetic interactions between the high-spin $(S=5 / 2) \mathrm{Fe}(\mathrm{III})$ centers. For C1, two quadrupole doublets are observed at room temperature and $5 \mathrm{~K}$, consistent with

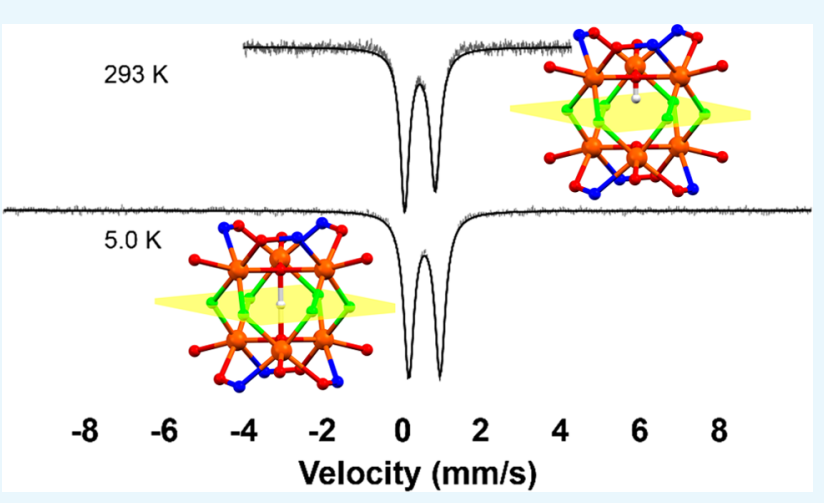
structural data from which discrete but disordered $\left[\mathrm{Fe}_{3}-\mu_{3}-\mathrm{O}\right]$ and $\left[\mathrm{Fe}_{3}-\mu_{3}-\mathrm{OH}\right]$ species were inferred. For $\mathbf{C 2}$, a single sharp quadrupole doublet with splitting intermediate between those determined for $\mathbf{C 1}$ was observed, consistent with the symmetric $\left[\mathrm{Fe}_{3}-\mu_{3}-\mathrm{O} \cdots \mathrm{H} \cdots \mu_{3}-\mathrm{O}-\mathrm{Fe}_{3}\right]$ species inferred crystallographically from the very short $\mu_{3}-\mathrm{O} \cdots \mu_{3}-\mathrm{O}$ separation. The differences in the physical properties of the complexes, as seen in the Mössbauer, X-ray, and magnetic data, are attributed to the conformational flexibility imparted by the nature of the linkages between the closely related ligands.

\section{INTRODUCTION}

Salicylaldoximes are excellent candidates for the synthesis of multinuclear clusters, as the phenolato and oximato groups are capable of acting as both chelating and bridging units. These salicylaldoximes are monoanionic when the phenol group is deprotonated and dianionic when both the phenol and oxime groups are deprotonated. Thus, the phenolato oxygen can act as a chelating unit for one metal, while the oximato oxygen serves to bridge a second metal (Figure 1).,

Several examples of this mode have been reported with nuclearities of two, ${ }^{3-5}$ three, ${ }^{6,7}$ and four. ${ }^{8,9}$ The investigation of oxo-bridged multinuclear Fe(III) materials has been a growing field of interest, as these oxo-bridged units are observed in various iron metalloproteins. ${ }^{10-19}$ Proteins such as ferritin,

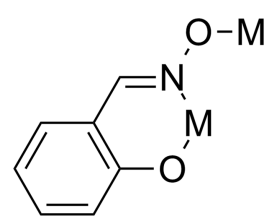

Figure 1. General $\mu_{2}: \eta^{1}: \eta^{1}: \eta^{1}$ coordination mode of the dianionic form of salicylaldoxime; $\mathrm{M}$, metal ion. which is used in mammalian iron storage, contain an extraordinary polynuclear iron-oxo core. ${ }^{20,21}$

Structural and magnetic studies of salicylaldoxime-based metal clusters of $\mathrm{M}_{3}-\mu_{3}-\mathrm{O}$ units have received increased interest after hexameric species were reported to be single molecule magnets (SMMs). ${ }^{2-26}$ There is now an extensive volume of work surrounding the coordination chemistry of $\mathrm{Mn}^{\mathrm{III}}$ clusters, which have been synthesized using derivatized salicylaldoxime ligands. ${ }^{25-30}$ However, the number of analogous iron-based magnetic materials that have been reported to date is comparatively low.

Our interest in the synthesis and characterization of polynuclear derivatized salicylaldoxime clusters ${ }^{31-37}$ began in 2009 with the synthesis and structural characterization of a hexacopper trihelicate complex, $\left[\mathrm{Cu}_{6}\left(\mu_{3}-\mathrm{OH}_{0.5}\right)_{2}\left(\mathrm{H}_{4} \mathrm{~L}-2 \mathrm{H}\right)_{3}\right]$ $\left(\mathrm{PF}_{6}\right)_{3}\left(1, \mathrm{H}_{4} \mathrm{~L}=3,3^{\prime}\right.$-[N,N'-dimethyl-1,6-hexanediaminobis(methylene)]bis[2-hydroxy-5-tert-butylbenzaldehyde

Received: April 28, 2021

Accepted: June 1, 2021

Published: June 15, 2021

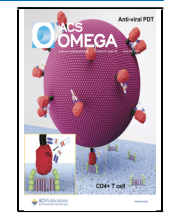


oxime]). ${ }^{38}$ There have been several analogous iron examples reported after the investigation of this copper complex. In 2012, Mason et al. reported an iron complex using a longer analogue of this ligand $\left[\mathrm{Fe}_{6}\left(\mu_{3}-\mathrm{OH}_{0.5}\right)_{2}\left(\mu_{2}-\mathrm{OH}\right)_{6}\left(\mathrm{H}_{4} \mathrm{~L}-2 \mathrm{H}\right)_{3}\right]$ $\left(\mathrm{BF}_{4}\right)_{3} \cdot 4 \mathrm{H}_{2} \mathrm{O} \cdot 9 \mathrm{MeOH} \quad\left(2, \mathrm{H}_{4} \mathrm{~L}=3,3^{\prime}-\left[N, N^{\prime}\right.\right.$-dimethyl-1,8octanediaminobis(methylene)]bis[2-hydroxy-5-tert-butylbenzaldehyde oxime]). ${ }^{39}$ They found that the increased length of the straps in the ligand led to enhanced flexibility and a subsequent favoring of an octahedral coordination environment at the iron centers. In 2010, a hexa-iron complex utilizing 2-hydroxyacetophenone oxime ligands (Me-sao) was reported to contain a similar metallic core, $\left[\mathrm{Fe}_{6}(\mathrm{Me}-\mathrm{sao})\left(\mu_{3}\right.\right.$ $\left.\left.\mathrm{OH}_{0.5}\right)_{2}\left(\mu_{2}-\mathrm{OH}\right)_{3}\left(\mu_{2}-\mathrm{OMe}\right)_{3}\right]^{3-}(3){ }^{40}$ Two analogous hexairon complexes using nonderivatized salicylaldoxime (sao), $\mathrm{Na}_{9}\left[\mathrm{Fe}_{6}\left(\mu_{3}-\mathrm{OH}_{0.5}\right)_{2}(\mathrm{sao})_{6}\left(\mu_{2}-\mathrm{OMe}\right)_{3}\left(\mu_{2}-\mathrm{OH}\right)_{3}\right]_{2}\left[\mathrm{Fe}_{3}(\mathrm{sao})_{6}\right]$ (4) and $\mathrm{Na}_{3}\left[\mathrm{Fe}_{6}\left(\mu_{3}-\mathrm{OH}_{0.5}\right)_{2}(\mathrm{sao})_{6}\left(\mu_{2}-\mathrm{OMe}\right)_{3}\left(\mu_{2}-\mathrm{OH}\right)_{3}\right]$ (5), have since been reported. ${ }^{41}$

Our study focuses on the hexa-iron complexes composed of metal triangles with the $\mathrm{M}_{3}-\mu_{3}-\mathrm{O}$ moiety. We report the syntheses and analyses of two hexa-iron complexes formed with derivatized "linked" and "nonlinked" salicylaldoxime ligands (Figure 2). We believe these are the first $\left[\mathrm{Fe}_{3}-\mu_{3}\right.$ -

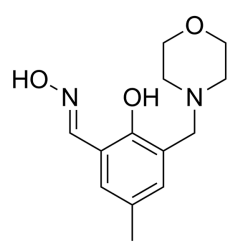

'non-linked' salicylaldoxime derivative

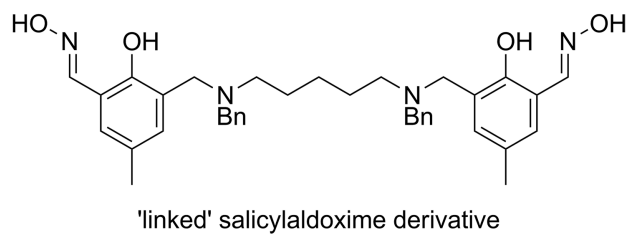

Figure 2. Chemical structures of $\mathrm{H}_{2} \mathrm{~L} 1$ (top) and $\mathrm{H}_{4} \mathrm{~L} 2$ (bottom).

$\left.\left(\mathrm{OH}_{0.5}\right)\right]_{2}$ complexes to feature six $\mu_{2}-\mathrm{F}$ linkers between the $\mathrm{Fe}_{3}$ triangles, in contrast to the more prevalent $\mu_{2}-\mathrm{OH}$ linkers or a mixture of $\mu_{2}-\mathrm{OH}$ and $\mu_{2}$-OMe linkers. The structural properties of these complexes will be discussed in relation to the Mössbauer and VT magnetic data.

\section{EXPERIMENTAL SECTION}

Synthesis. All reactions were performed under aerobic conditions using chemicals and solvents as received, unless otherwise stated. ${ }^{1} \mathrm{H}$ and ${ }^{13} \mathrm{C}$ NMR spectra were recorded on a Bruker Avance $500 \mathrm{MHz}$ spectrometer; $\delta$ values are relative to the corresponding residual solvent. Mass spectra were obtained using a Micromass ZMD 400 electrospray spectrometer. IR spectra were recorded on a Nicolet 5700 FT-IR spectrometer from Thermo Electron Corporation using an ATR sampling accessory. Elemental analyses were determined by the Campbell Microanalytical Laboratory at the University of Otago using crystalline samples, which had been crushed and dried in vacuo.

Synthesis of Ligands and Complexes. 2-Hydroxy-5methylbenzaldehyde was synthesized as described in the literature. ${ }^{42}$ The preparation of 3-(bromomethyl)-2-hydroxy5-methylbenzaldehyde (A), and the oxime precursors, was carried out by the procedure of Tasker and Schröder. ${ }^{43}$ Synthesis of the secondary amine, $N, N^{\prime}$-dibenzyl-1,5-pentanediamine (B), and oximes was carried out according to the procedure of Plieger et al. ${ }^{44}$

L 1 a (Precursor for $\left.\mathrm{H}_{2} \mathrm{~L} 1\right)$. 2-Hydroxy-5-methyl-3-(4morpholinomethyl)benzaldehyde. Solutions of A (1.27 g, $5.54 \mathrm{mmol}$ ) and morpholine $(1.31 \mathrm{~g}, 1.30 \mathrm{~mL}, 14.8 \mathrm{mmol})$, each in $\mathrm{CH}_{2} \mathrm{Cl}_{2}(60 \mathrm{~mL})$, were added simultaneously to a stirred solution of $\mathrm{Et}_{3} \mathrm{~N}(3.40 \mathrm{~g}, 4.68 \mathrm{~mL}, 14.8 \mathrm{mmol})$ in $\mathrm{CH}_{2} \mathrm{Cl}_{2}(80 \mathrm{~mL})$ over $30 \mathrm{~min}$. The resulting yellow solution was stirred for $24 \mathrm{~h}$ at RT. The solution was washed with water $(3 \times 100 \mathrm{~mL})$, and the organic phase was dried over anhydrous $\mathrm{Na}_{2} \mathrm{SO}_{4}$. Removal of the solvent afforded a yellow oil, which was further dried in vacuo. Yield (2.99 g, 86\%). IR ( $\mathrm{KBr}$ pellet): $1674(\mathrm{~s}), 1115(\mathrm{~s}), 1233(\mathrm{~m}) \mathrm{cm}^{-1}$. Anal. calcd for $\mathrm{C}_{13} \mathrm{H}_{17} \mathrm{NO}_{3}$ : C, 66.36; H, 7.28; N, 5.95. Found: C, 66.20; H, 7.42; N, 6.12. ${ }^{1} \mathrm{H} \mathrm{NMR}\left(\mathrm{CDCl}_{3}, 500 \mathrm{MHz}\right): \delta(\mathrm{ppm}) 2.30(\mathrm{~s}$, $3 \mathrm{H}), 2.57(\mathrm{br}, 4 \mathrm{H}), 3.67(\mathrm{~s}, 2 \mathrm{H}), 3.76(\mathrm{t}, J=4.76 \mathrm{~Hz}, 4 \mathrm{H})$, $7.20(\mathrm{~d}, J=1.72 \mathrm{~Hz}, 1 \mathrm{H}), 7.41(\mathrm{~d}, J=1.72 \mathrm{~Hz}, 1 \mathrm{H}), 10.21(\mathrm{~s}$, $1 \mathrm{H}) .{ }^{13} \mathrm{C} \mathrm{NMR}\left(\mathrm{CDCl}_{3}, 126 \mathrm{MHz}\right): \delta$ (ppm) 20.2, 53.1, 59.0, 66.7, 122.0, 123.4, 128.5, 129.5, 137.1, 158.7, 192.7. ESI-MS (+ve ion mode, $\mathrm{MeOH}$ ) $m / z: 235[\mathrm{M}+\mathrm{H}]^{+}$.

$\mathrm{H}_{2}$ L1. 2-Hydroxy-5-methyl-3-(4-morpholinomethyl)benzaldehyde Oxime. A solution of $\mathrm{KOH}(0.662 \mathrm{~g}, 11.8$ $\mathrm{mmol})$ in dry $\mathrm{EtOH}(100 \mathrm{~mL})$ was added to a solution of $\mathrm{NH}_{2} \mathrm{OH} \cdot \mathrm{HCl}(2.78 \mathrm{~g}, 11.8 \mathrm{mmol})$ in dry EtOH $(100 \mathrm{~mL})$. The resulting white precipitate was removed, and the filtrate was added to a solution of L1a $(2.78 \mathrm{~g}, 11.8 \mathrm{mmol})$ in dry EtOH $(200 \mathrm{~mL})$ over $30 \mathrm{~min}$. The resulting pale yellow solution was stirred for $24 \mathrm{~h}$ at RT. The solvent was removed, and the yellow solid was dissolved in $\mathrm{CHCl}_{3}(200 \mathrm{~mL})$, washed with water $(3 \times 100 \mathrm{~mL})$, and the organic phase was dried over anhydrous $\mathrm{Na}_{2} \mathrm{SO}_{4}$. Removal of the solvent afforded a yellow solid, which was washed with cold EtOH $(70 \mathrm{~mL})$. The resulting white powder was dried in vacuo. Yield (1.25 g, 42\%). mp 194.5-196.5 ${ }^{\circ} \mathrm{C}$. IR (KBr pellet): $1618(\mathrm{~s}), 2964(\mathrm{~m})$, $1471(\mathrm{~s}), 1267(\mathrm{~m}), 1111$ (s) $\mathrm{cm}^{-1}$. Anal. calcd for $\mathrm{C}_{13} \mathrm{H}_{18} \mathrm{~N}_{2} \mathrm{O}_{3}$ : C, 62.38; H, 7.25; N, 11.19. Found: C, 62.34; $\mathrm{H}, 7.34 ; \mathrm{N}, 10.95 .{ }^{1} \mathrm{H}$ NMR $\left(d_{6}\right.$-DMSO, $\left.500 \mathrm{MHz}\right): \delta(\mathrm{ppm})$ $2.03(\mathrm{~s}, 3 \mathrm{H}), 2.44(\mathrm{br}, 4 \mathrm{H}), 3.59(\mathrm{~s}, 2 \mathrm{H}), 3.59(\mathrm{t}, J=4.60 \mathrm{~Hz}$, $4 \mathrm{H}), 6.98(\mathrm{~d}, J=1.82 \mathrm{~Hz}, 1 \mathrm{H}), 7.22(\mathrm{~d}, J=1.87 \mathrm{~Hz}, 1 \mathrm{H}), 8.28$ $(\mathrm{s}, 1 \mathrm{H}) .{ }^{13} \mathrm{C}$ NMR $\left(d_{6}\right.$-DMSO, $\left.126 \mathrm{MHz}\right): \delta(\mathrm{ppm}) 20.5,53.1$, $66.5,118.4,123.1,126.8,127.9,131.7,147.2,153.5$. ESI-MS (+ve ion mode, $\mathrm{MeOH}) \mathrm{m} / z: 251[\mathrm{M}+\mathrm{H}]^{+}$.

L2a (Precursor for $\left.H_{4} L 2\right)$. 3,3'-[N, $N^{\prime}$-Dibenzyl-1,5pentanediaminobis(methylene)]bis[2-hydroxy-5-methylbenzaldehyde]. Solutions of $\mathbf{A}(1.00 \mathrm{~g}, 8.05 \mathrm{mmol})$ and $\mathbf{B}$ $(0.81 \mathrm{~g}, 2.77 \mathrm{mmol})$, each dissolved in dry $\mathrm{CH}_{2} \mathrm{Cl}_{2}(20 \mathrm{~mL})$, were added simultaneously to a stirred solution of $\mathrm{Et}_{3} \mathrm{~N}(1.11$ g, $8.05 \mathrm{mmol})$ in dry $\mathrm{CH}_{2} \mathrm{Cl}_{2}(30 \mathrm{~mL})$ over $30 \mathrm{~min}$. The yellow solution was stirred for $24 \mathrm{~h}$ at RT. The solution was washed with water $(3 \times 100 \mathrm{~mL})$, and the organic phase dried over anhydrous $\mathrm{Na}_{2} \mathrm{SO}_{4}$. Removal of the solvent afforded a bright yellow solid, which was further dried in vacuo. Yield (2.04 g, 86\%). IR (KBr pellet): 1681 (s), 2851 (s), 3028 (m), $1471(\mathrm{~m}) \mathrm{cm}^{-1}$. Anal. calcd for $\mathrm{C}_{37} \mathrm{H}_{42} \mathrm{~N}_{2} \mathrm{O}_{4} \cdot \mathrm{H}_{2} \mathrm{O}$ : C, 74.47; $\mathrm{H}, 7.43$; N, 4.69. Found: C, 74.61; H, 7.37; N, 4.73. ${ }^{1} \mathrm{H}$ NMR $\left(\mathrm{CDCl}_{3}, 500 \mathrm{MHz}\right): \delta(\mathrm{ppm}) 1.22(\mathrm{q}, J=7.53 \mathrm{~Hz}, 2 \mathrm{H}), 1.53$ $(\mathrm{q}, J=6.85 \mathrm{~Hz}, 4 \mathrm{H}), 2.28(\mathrm{~s}, 6 \mathrm{H}), 2.45(\mathrm{t}, J=7.29 \mathrm{~Hz}, 4 \mathrm{H})$, $3.61(\mathrm{~s}, 4 \mathrm{H}), 3.71(\mathrm{~s}, 4 \mathrm{H}), 7.15(\mathrm{~s}, 2 \mathrm{H}), 7.29(\mathrm{~d}, J=7.69 \mathrm{~Hz}$, $4 \mathrm{H}), 7.34$ (d, $J=7.28 \mathrm{~Hz}, 4 \mathrm{H}), 7.37$ (s, 2H), 7.43 (d, $J=1.62$ 
Table 1. Crystal Data and Structural Refinement for Complexes C1 and C2

\begin{tabular}{|c|c|c|}
\hline data & C1 & $\mathrm{C} 2$ \\
\hline empirical formula & $\mathrm{C}_{39} \mathrm{H}_{51} \mathrm{~F}_{3} \mathrm{Fe}_{3} \mathrm{~N}_{6} \mathrm{O}_{10} \cdot \mathrm{C}_{39} \mathrm{H}_{50} \mathrm{~F}_{3} \mathrm{Fe}_{3} \mathrm{~N}_{6} \mathrm{O}_{10} \cdot \mathrm{BF}_{4}$ & $\mathrm{C}_{116} \mathrm{H}_{131} \mathrm{~F}_{6} \mathrm{Fe}_{6} \mathrm{~N}_{13} \mathrm{O}_{14} \cdot 3 \mathrm{BF}_{4}$ \\
\hline formula weight & 2062.61 & 2640.86 \\
\hline crystal system & triclinic & monoclinic \\
\hline space group & $P \overline{1}$ & $P 2_{1} / c$ \\
\hline$a(\AA)$ & $16.8193(10)$ & $17.9936(4)$ \\
\hline$b(\AA)$ & $17.3271(10)$ & $37.0613(7)$ \\
\hline$c(\AA)$ & $21.1897(15)$ & $20.4370(14)$ \\
\hline$\alpha(\operatorname{deg})$ & $107.161(8)$ & 90 \\
\hline$\beta(\operatorname{deg})$ & $99.537(7)$ & $113.409(8)$ \\
\hline$\gamma(\operatorname{deg})$ & $100.103(7)$ & 90 \\
\hline volume $\left(\AA^{3}\right)$ & $5651.6(7)$ & $12507.0(12)$ \\
\hline$Z\left(Z^{\prime}\right)$ & $1(0.5)$ & $4(1)$ \\
\hline reflections collected/unique data & $77177 / 18822\left[R_{\mathrm{int}}=0.126\right]$ & $130760 / 21266\left[R_{\mathrm{int}}=0.197\right]$ \\
\hline wavelength $(\AA)$ & 1.5418 & 1.5418 \\
\hline data collection limits & $6.60<\theta<65.40^{\circ}$ & $6.55<\theta<65.08^{\circ}$ \\
\hline completeness & 0.977 & 0.997 \\
\hline temperature $(\mathrm{K})$ & 160 & 163 \\
\hline data/restraints/parameters & $18822 / 217 / 1098$ & $21266 / 1090 / 1565$ \\
\hline GOOF & 1.037 & 0.970 \\
\hline final $R$ indices $(I>2 \sigma I)$ & $R_{1}=0.1491(0.1049) w R_{2}=0.3259(0.2810)$ & $R_{1}=0.1894(0.1012) w R_{2}=0.3043(0.2518)$ \\
\hline residual density $\left(\mathrm{e}^{-} / \AA^{3}\right)$ & $1.62 /-0.84$ & $0.76 /-0.52$ \\
\hline CCDC no. & 2048582 & 2048583 \\
\hline
\end{tabular}

$\mathrm{Hz}, 2 \mathrm{H}), 10.32(\mathrm{~s}, 2 \mathrm{H}) \cdot{ }^{13} \mathrm{C} \mathrm{NMR}\left(\mathrm{CDCl}_{3}, 126 \mathrm{MHz}\right): \delta$ (ppm) 20.3, 24.7, 26.0, 55.0, 55.5, 58.2, 122.4, 124.4, 127.6, 128.2, 128.3, 128.5, 129.3, 136.3, 137.1, 159.2, 191.8. ESI-MS (+ve ion mode, $\mathrm{MeOH}) \mathrm{m} / z: 580[\mathrm{M}+\mathrm{H}]^{+}$.

$\mathrm{H}_{4}$ L2. 3,3'-[N, $\mathrm{N}^{\prime}$-Dibenzyl-1,5-pentanediaminobis(methylene)]bis[2-hydroxy-5-methylbenzaldehyde Oxime]. A solution of $\mathrm{KOH}(0.276 \mathrm{~g}, 4.92 \mathrm{mmol})$ in dry EtOH $(50$ $\mathrm{mL})$ was added to a solution of $\mathrm{NH}_{2} \mathrm{OH} \cdot \mathrm{HCl}(0.342 \mathrm{~g}, 4.92$ $\mathrm{mmol})$ in dry EtOH $(50 \mathrm{~mL})$. The resulting white precipitate was removed, and the filtrate was added to a solution of L2a $(1.00 \mathrm{~g}, 1.64 \mathrm{mmol})$ in dry toluene $(30 \mathrm{~mL})$ over $30 \mathrm{~min}$. The pale yellow solution was stirred for further $48 \mathrm{~h}$ at RT, after which time a white precipitate was obtained. The combined residues were filtered, washed with cold chloroform $(3 \times 30$ $\mathrm{mL})$ followed by cold EtOH $(3 \times 30 \mathrm{~mL})$. The final yellow waxy product was dried in vacuo. Yield (0.892 g, 85\%). IR (KBr pellet): $1612(\mathrm{~m}), 1280(\mathrm{~s}), 1022(\mathrm{~m}) \mathrm{cm}^{-1}$. Anal. calcd for $\mathrm{C}_{37} \mathrm{H}_{44} \mathrm{~N}_{4} \mathrm{O}_{4}$ : C, 73.00; H, 7.29; N, 9.20. Found: C, 72.87; $\mathrm{H}, 6.98 ; \mathrm{N}, 8.92 .{ }^{1} \mathrm{H}$ NMR $\left(\mathrm{CDCl}_{3}, 500 \mathrm{MHz}\right): \delta(\mathrm{ppm}) 1.18$ (q, $J=7.22 \mathrm{~Hz}, 2 \mathrm{H}), 1.51(\mathrm{q}, J=6.83,4 \mathrm{H}), 2.25(\mathrm{~s}, 6 \mathrm{H}), 2.44$ $(\mathrm{t}, J=6.99 \mathrm{~Hz}, 4 \mathrm{H}), 3.59(\mathrm{~s}, 4 \mathrm{H}), 3.69(\mathrm{~s}, 4 \mathrm{H}), 6.86(\mathrm{br}, 2 \mathrm{H})$, $7.26(\mathrm{br}, 4 \mathrm{H}), 7.28(\mathrm{br}, 4 \mathrm{H}), 7.29(\mathrm{br}, 4 \mathrm{H}), 7.33(\mathrm{t}, J=7.82$ $\mathrm{Hz}, 4 \mathrm{H}), 8.48(\mathrm{~s}, 2 \mathrm{H}) .{ }^{13} \mathrm{C} \mathrm{NMR}\left(\mathrm{CDCl}_{3}, 126 \mathrm{MHz}\right): \delta$ (ppm) 20.4, 24.6, 25.7, 52.6, 56.5, 58.1, 118.2, 122.4, 122.7, 126.6, 127.6, 128.1, 128.5, 129.5, 131.4, 136.8, 147.7, 154.2. ESI-MS (+ve ion mode, $\mathrm{MeOH}) \mathrm{m} / z: 609[\mathrm{M}+\mathrm{H}]^{+}$.

$\left[\mathrm{Fe}_{6}\left(\mathrm{OH}_{0.5}\right)_{2} \mathrm{~F}_{6}\left(\mathrm{H}_{2} \mathrm{~L} 1-\mathrm{H}\right)_{6}\right]\left(\mathrm{BF}_{4}\right)_{3}(\mathrm{C} 1)$. To the ligand $\mathrm{H}_{2} \mathbf{L} \mathbf{1}$ $(0.125 \mathrm{~g}, 0.500 \mathrm{mmol})$ dissolved in $\mathrm{MeOH}(12.5 \mathrm{~mL})$ was added $\mathrm{Fe}\left(\mathrm{BF}_{4}\right)_{2} \cdot 6 \mathrm{H}_{2} \mathrm{O}(0.169 \mathrm{~g}, 0.500 \mathrm{mmol})$ in $\mathrm{MeOH}(12.5$ $\mathrm{mL})$. After full dissolution, pyridine $(2 \mathrm{~mL})$ was added to the maroon-colored solution. The solution was stirred for $3 \mathrm{~h}$, filtered, and the filtrate was left to evaporate slowly. X-ray quality crystals were produced after 2 weeks. The crystals obtained were washed with diethyl ether and dried in vacuo. Yield (0.202 g, 59\%). Anal. calcd for $\mathrm{C}_{78} \mathrm{H}_{102} \mathrm{~B}_{3} \mathrm{~F}_{18} \mathrm{Fe}_{6} \mathrm{~N}_{12} \mathrm{O}_{20}$. $\mathrm{H}_{2} \mathrm{O} \cdot 2$ pyr: C, 43.79; H, 4.76; N, 8.13. Found: C, 43.94; $\mathrm{H}$,
4.92; N, 7.98. IR (KBr pellet): 1617(s), 1465(vs), 1084(m), $520(\mathrm{~s}), 454(\mathrm{~m}) \mathrm{cm}^{-1}$.

$\left[\mathrm{Fe}_{6}\left(\mathrm{OH}_{0.5}\right)_{2} \mathrm{~F}_{6}\left(\mathrm{H}_{4} \mathrm{~L} 2-2 \mathrm{H}\right)_{3}\right]\left(\mathrm{BF}_{4}\right)_{3} \quad(\mathrm{C} 2)$. To the ligand $\mathrm{H}_{4} \mathbf{L} 2$ (0.304 g, $0.500 \mathrm{mmol}$ ) dissolved in $\mathrm{MeOH}(12.5 \mathrm{~mL})$ was added $\mathrm{Fe}\left(\mathrm{BF}_{4}\right)_{2} \cdot 6 \mathrm{H}_{2} \mathrm{O}(0.348 \mathrm{~g}, 1.00 \mathrm{mmol})$ in $\mathrm{MeOH}(12.5$ $\mathrm{mL})$. After full dissolution, pyridine $(2 \mathrm{~mL})$ was added to the maroon-colored solution. The solution was stirred for $3 \mathrm{~h}$, filtered, and then the filtrate was left to evaporate slowly. X-ray quality crystals were produced after 2 weeks. The crystals obtained were washed with diethyl ether and dried in vacuo. Yield (0.190 g, 14\%). Anal. calcd for $\mathrm{C}_{111} \mathrm{H}_{127} \mathrm{~B}_{3} \mathrm{~F}_{18} \mathrm{Fe}_{6} \mathrm{~N}_{12} \mathrm{O}_{14}$. $5 \mathrm{H}_{2} \mathrm{O}$.pyr: C, 51.00; H, 5.24; N, 6.67. Found: C, 50.80; H, 5.02; N, 6.84. IR (KBr pellet): 1617(s), 1460(vs), 1293 (s), 1084(m), $759(\mathrm{~m}), 522(\mathrm{~m}) \mathrm{cm}^{-1}$.

X-ray Structural Determination. Single-crystal X-ray data $\mathrm{C} 1$ and $\mathrm{C2}$ were collected at -113 and $-110{ }^{\circ} \mathrm{C}$, respectively, using $\mathrm{Cu} \mathrm{K} \alpha(\lambda=1.54178 \AA)$ radiation on a Rigaku-Spider diffractometer equipped with a curved imageplate detector. Data collection was carried out with the CrystalClear software package, and data reduction and cell refinement were carried out with PROCESS-AUTO and FSProcess. All structures were solved using direct methods with ShelXS and further refined with ShelXL, ${ }^{45,46}$ as implemented in Olex $2 .{ }^{47}$ All non-hydrogen atoms were refined anisotropically, and hydrogen atoms were included in the ideal positions with a fixed $U_{\text {iso }}$ value, riding on their respective nonhydrogen atoms.

For complex $\mathbf{C 1}$, the cation occupied only $75 \%$ of the unit cell and in the void volume lurks, inter alia, two $\mathrm{BF}_{4}^{-}$ions, a water molecule, and two pyridine molecules, which are also required to fit the microanalytical data. On the other hand, complex C2 is tightly packed in its unit cell, although the $6 \times$ $\mathrm{H}_{2} \mathrm{O}$ solvate species within the solvent mask are seen as just 5 $\times \mathrm{H}_{2} \mathrm{O}$ in microanalytical data.

Magnetic Measurements. Variable-temperature, direct current $(\mathrm{dc})$ magnetic susceptibility and magnetization measurements on powdered microcrystalline samples of each 
complex were performed using a Quantum Design MPMS-XL SQUID magnetometer equipped with a $7 \mathrm{~T}$ dc magnet. Diamagnetic corrections were applied to the observed paramagnetic susceptibilities using Pascal's constants. ${ }^{48}$

Mössbauer Measurements. ${ }^{57} \mathrm{Fe}$ Mössbauer spectra were recorded with a ${ }^{57} \mathrm{Co}$ source in a $\mathrm{Rh}$ matrix on an SEE Co. (Science Engineering \& Education Co., MN) spectrometer equipped with a closed-cycle refrigerator system. Data were collected in a constant acceleration mode in transmission geometry. Isomer shifts are given relative to metallic iron foil at room temperature. Analysis of the spectra was conducted using the WMOSS program (SEE Co., formerly WEB Research Co. Edina, MN).

\section{RESULTS AND DISCUSSION}

C1 and C2 were isolated as dark maroon orthorhombic-shaped single crystals by slow evaporation of the complexation filtrate at room temperature. The coordination of iron to the ligand, accompanied by oxidation to $\mathrm{Fe}$ (III), was immediately evidenced by a color change of the ligand suspension from pale yellow to dark maroon upon addition of $\mathrm{Fe}\left(\mathrm{BF}_{4}\right)_{2} \cdot 6 \mathrm{H}_{2} \mathrm{O}$. The data measurement and other refinement parameters for crystal structures of $\mathbf{C 1}$ and $\mathbf{C 2}$ are given in Table 1.

Complex $\mathbf{C 1}$ crystallizes in the triclinic space group $P \overline{1}$ with two structurally similar half-clusters in the asymmetric unit. Crystallographic inversion symmetry generates the full cluster. Each independent unit of $\mathrm{C} 1$ comprises $6 \times \mathrm{Fe}(\mathrm{III})(+18), 6 \times$ $\mathrm{F}(-6), 2 \times\left(\mathrm{OH}_{0.5}\right)(-3)$, and $6 \times\left(\mathrm{H}_{2} \mathrm{Ll}\right)$ ligands, all of which are present in an overall singly deprotonated form as $\left(\mathrm{H}_{2} \mathbf{L} \mathbf{1}-\mathrm{H}\right)$. Thus, the overall charge of the cation, +3 , is balanced by $3 \times \mathrm{BF}_{4}^{-}$within the lattice. The complex, C1, contains two $\left[\mathrm{Fe}_{3}{ }_{3} \mathrm{II}\right]$ units, each with a central $\mu_{3}$-O-atom. The central oxygen atoms are displaced from the metal planes toward the central cavity of the complex by 0.154 and $0.159 \AA$. The short distances $(2.639(11)$ and $2.681(8) \AA)$ between the pairs of oxygen atoms suggest that each cluster contains a disordered $\mu_{3}$-oxo $/ \mu_{3}$-hydroxo moiety with the proton most likely being asymmetrically placed between the two oxygen atoms. ${ }^{49}$ Thus, the two triangles are formulated as $\left[\mathrm{Fe}_{3}{ }^{\mathrm{III}}\left(\mu_{3^{-}}\right.\right.$ $\mathrm{O})]^{7+}$ and $\left[\mathrm{Fe}_{3}{ }^{\mathrm{III}}\left(\mu_{3}-\mathrm{OH}\right)\right]^{8+}$ and are disordered by the inversion center. These two triangles are connected via six $\mu_{2}$-fluoride groups (Figure 3 ), such that each Fe(III) within the upper triangle is connected to two $\mathrm{Fe}$ (III) ions within the lower triangle by two $\mu_{2}$-F groups. The triangles of iron atoms are rotated by exactly $60^{\circ}$ to each other as a result of the inversion center and are parallel. Selected structural parameters of $\mathbf{C 1}$ are shown in Table 2.

Each $\mathrm{Fe}$ (III) atom sits in an octahedral geometry where equatorial positions are taken by an oximato $\mathrm{N}$-atom and a phenolato $\mathrm{O}$-atom from one ligand, a $\mu_{2}-\mathrm{F}$ group and the $\mu_{3}$ $\mathrm{O} / \mathrm{OH}$ group, while the axial positions are coordinated by an oximato $\mathrm{O}$-atom from a neighboring ligand and a $\mu_{2}-\mathrm{F}$ group. The distances between amine $\mathrm{N}$-atoms and phenolato $\mathrm{O}$-atoms within a given ligand all fall in the range of 2.570(11)$2.847(12) \AA$ and are consistent with hydrogen-bond interactions.

Complex C2 crystallizes in the monoclinic $P 2_{1} / c$ space group. The cation of the complex, $\mathbf{C 2}$, is formed from $6 \times$ $\mathrm{Fe}(\mathrm{III})(+18), 3 \times\left(\mathrm{H}_{4} \mathrm{~L} 2-2 \mathrm{H}\right)(-6), 6 \times \mathrm{F}(-6)$, and $2 \times$ $\left(\mathrm{OH}_{0.5}\right)(-3)$. The overall +3 charge is balanced by $3 \times \mathrm{BF}_{4}^{-}$ within the lattice, although only one of these was crystallographically observed. The complex C2, like C1, is also composed of two, in this case, near-parallel $\mathrm{Fe}_{3}{ }^{\mathrm{III}}$ triangles
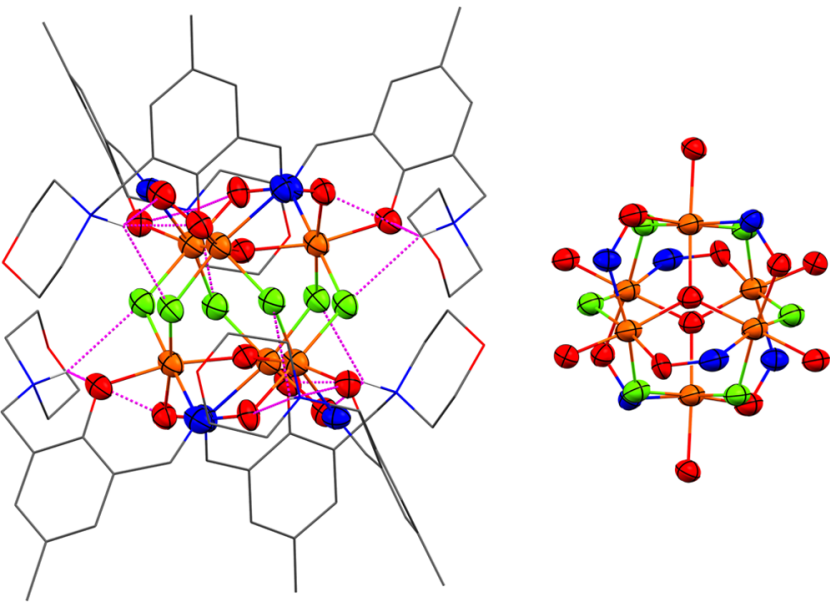

Figure 3. Left: the cation, $\left[\left(\mathrm{Fe}_{6}\left(\mathrm{OH}_{0.5}\right)_{2} \mathrm{~F}_{6}\left(\mathrm{H}_{2} \mathbf{L} \mathbf{1}-\mathrm{H}\right)_{6}\right)\right]^{3+}$, of $\mathbf{C 1}$ (noninteracting $\mathrm{H}$ atoms are omitted for clarity; $\mathrm{C}$, gray; $\mathrm{N}$, blue; $\mathrm{O}$, red; F, green; Fe, orange; $\mathrm{H}$, white; hydrogen bonds, pink; ellipsoids are drawn at the $30 \%$ probability level). Right: off-axis view of the core along the $\mu_{3}-\mathrm{O} \cdots \mu_{3}-\mathrm{O}$ axis.

that are connected through the twisted amine straps between the two salicylaldoxime "heads" on either end of each ligand molecule and six $\mu_{2}-\mathrm{F}$ groups.

Each triangle is formed of three $\mathrm{Fe}$ (III) ions that are bridged by oximato $(-\mathrm{N}-\mathrm{O}-)$ and oxo/hydroxo $\left(\mathrm{O}^{2-} / \mathrm{OH}^{-}\right)$groups. Each $\mathrm{Fe}(\mathrm{III})$ sits in an octahedral geometry, and the equatorial and axial positions around each $\mathrm{Fe}$ (III) are occupied by the same groups as in $\mathbf{C 1}$. Thus, the approximately parallel metal triangles of $\mathrm{C} 2$ are twisted by almost exactly $60^{\circ}$. As observed in $\mathrm{C1}$, the oximato bridging sequence on both metal triangles of $\mathrm{C} 2$ is also $\mathrm{Fe}-\mathrm{N}-\mathrm{O}-\mathrm{Fe}$. The $\mu_{3}$-O-atoms within the triangles of $\mathrm{C} 2$ are shifted by $0.303 \AA$ from the metal planes toward the internal cavity of the complex, leading to a short $\mathrm{O} \cdots \mathrm{O}$ separation of $2.430(8) \AA$, suggesting the presence of a proton symmetrically placed between the $\mu_{3}$-O-atoms (Figure $4) .{ }^{49}$ Important structural parameters, including $\mu_{3}-\mathrm{O} \cdots \mu_{3}-\mathrm{O}$ distances between $\mathrm{Fe}_{3} \mathrm{O}$ triangles of previously reported analogous hexa-iron complexes, are shown in Table 2. The $\mu_{3}-\mathrm{O} \cdots \mu_{3}-\mathrm{O}$ distances for the complexes 2,4 , and 5 are very similar to each other at $2.472(5)-2.561(16) \AA$, despite complex 2 containing flexible derivatized salicylaldoxime ligands and complexes $\mathbf{4}$ and $\mathbf{5}$ containing salicylaldoxime itself. In comparison to these numbers, the corresponding distances for C1 $(2.639(11)$ and $2.681(8) \AA)$ and C2 $(2.430(8) \AA)$ are significantly different from those reported for related hexa-iron(III) species and from each other. In C2, the $\mathrm{H}$ atoms bound to the amine $\mathrm{N}$-atoms on either end of each ligand appear to form moderately strong hydrogen bonds with the phenolato $\mathrm{O}$-atoms of the same ligand, falling in the range of $2.679(12)-2.828(10) \AA$. The $\mathrm{Fe}-\mu_{3}-\mathrm{O} / \mathrm{Fe}-\mu_{3}-\mathrm{OH}$ bond lengths in $\mathbf{C l}$ are similar to those reported in the literature but are noticeably shorter than those of $\mathbf{C 2}$. The $\mathrm{Fe}-\mu_{2}-\mathrm{F}-\mathrm{Fe}$ angles in $\mathbf{C} 1$ and $\mathbf{C} 2$ are observed to be larger than those previously reported in the literature for $\mu_{2}-\mathrm{OH}$ and $\mu_{2}$-OMe bridges. ${ }^{39,41}$ The amine straps in $\mathbf{C 2}$ are more flexible than the longer amine straps in 2 , as they bring the triangles closer to each other. The simplest salicylaldoxime ligands in $\mathbf{4}$ and 5 bring the triangles closer to each other than in complex C1. Moreover, the displacements of the $\mu_{3}$-O-atom from the metal triads in both units of the complex $\mathbf{C l}$ are observed to be smaller than those reported for $\mathbf{2 - 5}$, as well as C2 (Table 2); 
Table 2. Comparison of Important Structural Parameter Values of the Complexes 2-5 with $\mathrm{C} 1$ and $\mathrm{C2}^{b}$

\begin{tabular}{|c|c|c|c|c|c|c|}
\hline parameter & 2 & 3 & 4 & 5 & $\mathrm{C} 1$ & C2 \\
\hline $\mathrm{Fe} \cdots \mathrm{Fe}(\AA)^{a}$ & $3.392(2)-3.447(2)$ & $3.441(1)$ & $3.439(1)$ & $3.379(2)-3.522(2)$ & $3.262(2)-3.281(2)$ & $3.407(2)-3.446(2)$ \\
\hline $\mathrm{O} \cdots \mathrm{O}(\AA)^{a}$ & $2.526(10)$ & $2.472(5)$ & $2.518(5)$ & $2.532(6)$ & $2.639(11)-2.681(8)$ & $2.430(8)$ \\
\hline $\begin{array}{l}\mu_{3}-\mathrm{O} \\
\text { displacement } \\
\text { from } \mathrm{Fe}_{3} \text { plane } \\
(\AA)^{a}\end{array}$ & 0.317 & 0.331 & 0.330 & $0.263-0.358$ & $0.154-0.159$ & 0.303 \\
\hline $\mathrm{Fe}-\mu_{3}-\mathrm{O}(\AA)^{a}$ & $1.978(5)-2.019(7)$ & $2.014(1)$ & $2.011(1)-2.013(1)$ & $1.970(5)-2.081(5)$ & $1.867(4)-1.927(5)$ & $1.971(5)-2.020(5)$ \\
\hline $\mathrm{Fe}-\mathrm{N}_{\text {oximato }}(\AA)^{a}$ & $2.104(8)-2.138(6)$ & $2.118(2)$ & $2.108(3)$ & $2.093(6)-2.147(5)$ & $2.107(6)-2.139(6)$ & $2.075(9)-2.147(7)$ \\
\hline $\begin{array}{c}\mathrm{Fe}-\mathrm{O}_{\text {phenolato }} \\
(\AA)^{d{ }^{2}}\end{array}$ & $1.892(6)-1.920(1)$ & $1.935(2)$ & $1.915(2)$ & $1.919(4)-1.942(5)$ & $1.894(4)-1.979(6)$ & $1.902(6)-1.941(5)$ \\
\hline $\mathrm{Fe}-\mathrm{O}_{\text {oximato }}(\AA)^{a}$ & $1.951(8)-2.002(5)$ & $1.980(2)$ & $2.004(2)$ & $1.961(5)-2.019(4)$ & $1.967(5)-2.008(6)$ & $1.941(6)-1.984(7)$ \\
\hline $\mathrm{Fe}-\mu_{2}-\mathrm{X}(\AA)^{a}$ & $1.943(5)-2.112(6)$ & $2.019(1)-2.071(2)$ & $2.000(2)-2.115(2)$ & $1.981(5)-2.114(5)$ & $1.955(5)-2.068(4)$ & $1.947(4)-2.060(4)$ \\
\hline $\begin{array}{l}\mathrm{Fe}-\mu_{2}-\mathrm{X}-\mathrm{Fe} \\
(\mathrm{deg})^{a}\end{array}$ & $102.4(2)-104.0(3)$ & $98.4(1)-101.9(1)$ & $97.7(1)-103.3(1)$ & $97.4(2)-104.5(2)$ & $121.1(2)-123.7(2)$ & $126.0(2)-131.8(2)$ \\
\hline
\end{tabular}

${ }^{a}$ For complex 4, the stated values are for the hexa-iron cluster only. ${ }^{b} \mathrm{CCDC}$ deposition numbers: 863633 (2), ${ }^{39} 755042$ (3), ${ }^{40} 861227$ (4), ${ }^{41}$ $861228(5),{ }^{41} 2048582($ C1), and 2048583 (C2).

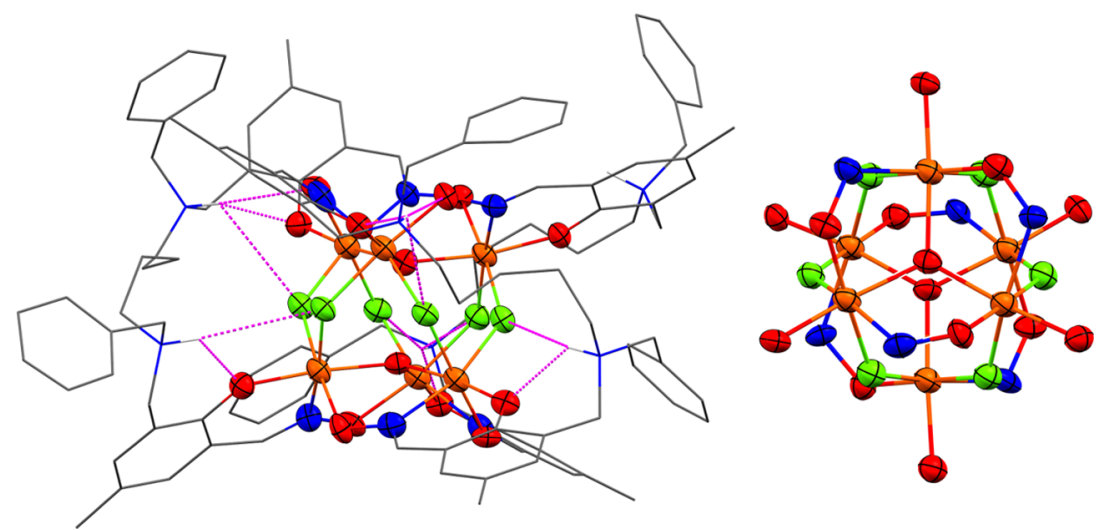

Figure 4. Left: the cation, $\left[\left(\mathrm{Fe}_{6}\left(\mathrm{OH}_{0.5}\right)_{2} \mathrm{~F}_{6}\left(\mathrm{H}_{2} \mathbf{L 2}-2 \mathrm{H}\right)_{6}\right)\right]^{3+}$, of $\mathbf{C 2}$ (noninteracting $\mathrm{H}$ atoms are omitted for clarity; C, gray; N, blue; O, red; F, green; $\mathrm{Fe}$, orange; $\mathrm{H}$, white; hydrogen bonds, pink; ellipsoids are drawn at the $30 \%$ probability level). Right: off-axis view of the core along the $\mu_{3}$ $\mathrm{O} \cdots \mu_{3}-\mathrm{O}$ axis.

this is coupled with the noticeably shorter $\mathrm{Fe}-\mu_{3}-\mathrm{O}(\mathrm{H})$ separations, compared to other species in Table 2 except $\mathbf{5}$ and C2. The differences in $\mathbf{C 1}$ compared to those in the other species are attributed to the crystallographic disorder imposed on the $\mathrm{Fe}-\mu_{3}-\mathrm{O} / \mathrm{Fe}-\mu_{3}-\mathrm{OH}$ moieties, apparent also in the ellipsoids of the central $\mathrm{O}$-atoms, which are elongated along the $\mu_{3}-\mathrm{O} \cdots \mu_{3}-\mathrm{O}$ axis.

Complexes $\mathbf{C 1}$ and $\mathbf{C 2}$ differ in having a staggered arrangement of the $\mathrm{Fe}_{3}$ triangles, compared to 2-5, which have nearly eclipsing to perfectly eclipsing configurations. This leads to each bridging $\mu_{2}-\mathrm{F}$ being subjected to a marked trans effect with $\mathrm{Fe}-\mathrm{F}$ bonds trans to $\mathrm{Fe}-\mathrm{O}$ having substantially greater $\mathrm{Fe}-\mathrm{F}$ separations (by $\sim 0.07 \AA$ ) than those $\mathrm{Fe}-\mathrm{F}$ bonds trans to $\mathrm{Fe}-\mathrm{N}$ bonds. A similar effect is observed for the hexa- $\mu_{2}-\mathrm{OH}$ bonds on 2 . Interestingly, in complexes 3-5, the $\mathrm{Fe}-\mu_{2}-\mathrm{O}-\mathrm{CH}_{3}$ bonds are all trans to $\mathrm{Fe}-\mathrm{O}$ bonds, whereas the $\mathrm{Fe}-\mu_{2}-\mathrm{OH}$ bonds are all trans to $\mathrm{Fe}-\mathrm{N}$ bonds.

Mössbauer Measurements and Discussion. The Mössbauer measurements were performed on C1 and C2 at 293 and $5 \mathrm{~K}$. Parameters derived from fitting the spectra are summarized in Table 3.

The hexa-iron complexes $\mathbf{C} 1$ and $\mathbf{C 2}$ were observed to contain only high-spin iron, $S=5 / 2$, according to the values modeled for chemical isomer shift $(\delta)$ and electric quadrupole splitting $\left(\Delta E_{\mathrm{Q}}\right)^{2,50,51}$ The room-temperature Mössbauer spectrum of $\mathbf{C 1}$ (Figure 5) revealed a pair of quadrupole
Table 3. Fitting Parameters of ${ }^{57} \mathrm{Fe}$ on $\mathrm{C} 1$ and $\mathrm{C} 2$ at Lower and Higher Temperatures $\left(\delta=\right.$ Isomer Shift, $\Delta E_{Q}=$ Quadrupole Splitting, $\Gamma=$ Half-Height Line Width, $I=$ Intensity)

\begin{tabular}{|c|c|c|c|c|c|}
\hline$T(\mathrm{~K})$ & $\delta(\mathrm{mm} / \mathrm{s})$ & $\Delta E_{\mathrm{Q}}(\mathrm{mm} / \mathrm{s})$ & $\Gamma_{\mathrm{L}}(\mathrm{mm} / \mathrm{s})$ & $\Gamma_{\mathrm{R}}(\mathrm{mm} / \mathrm{s})$ & $I(\%)$ \\
\hline \multicolumn{6}{|c|}{$\mathrm{C} 1$} \\
\hline \multirow[t]{2}{*}{293} & 0.40 & 1.18 & 0.35 & 0.35 & 55 \\
\hline & 0.40 & 0.57 & 0.40 & 0.40 & 45 \\
\hline \multirow[t]{3}{*}{$5.0^{a}$} & 0.57 & 1.22 & 0.28 & 0.28 & 50 \\
\hline & 0.55 & 0.82 & 0.44 & 0.44 & 50 \\
\hline & \multicolumn{5}{|c|}{$\mathrm{C} 2$} \\
\hline 293 & 0.43 & 0.77 & 0.27 & 0.31 & 100 \\
\hline 5.0 & 0.54 & 0.79 & 0.32 & 0.32 & 100 \\
\hline
\end{tabular}

${ }^{a}$ See the text.

doublets, of approximately equal area, both with an isomer shift of $0.40 \mathrm{~mm} / \mathrm{s}$ but with quadrupole splittings of 1.18 and $0.57 \mathrm{~mm} / \mathrm{s}$. This is attributed to the asymmetry that occurs within this complex at room temperature (and at the crystallographic data collection temperature) and is masked by the crystallographic disorder discussed above. The smaller quadrupole doublet is associated with the $\mu_{3}-\mathrm{OH}-\mathrm{Fe}_{3}$ moiety and the larger with the $\mu_{3}-\mathrm{O}-\mathrm{Fe}_{3}$ moiety. Nonetheless, both values are unusually high for $\mathrm{Fe}_{3} \mathrm{O}(\mathrm{H})$ moieties and may be attributed to the short $\mathrm{Fe}-\mu_{3}-\mathrm{O}$ bonds. The isosceles-triangled 


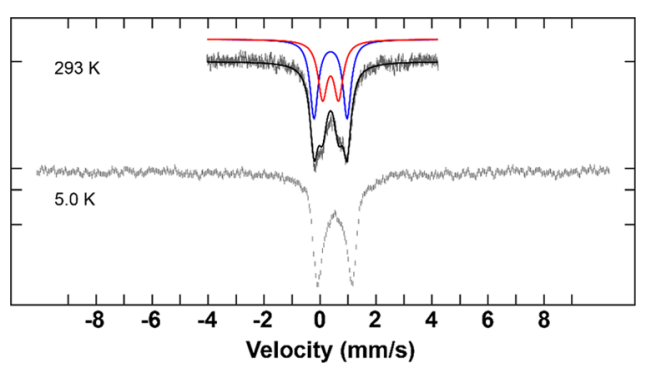

Figure 5. ${ }^{57} \mathrm{Fe}$ Mössbauer spectra of complex $\mathbf{C 1}$ at high and low temperatures, overlaid with corresponding fits using the parameters given in Table 3 at high temperature.

species $\left[\mathrm{Fe}_{3} \mathrm{O}(\mathrm{TIEO})_{2}\left(\mathrm{O}_{2} \mathrm{CPh}\right)_{2} \mathrm{Cl}_{3}\right]$ (6) (H-TIEO = 1,1,2Tris(N-methylimidazol-2-yl)-1-hydroxyethane), where two $\mathrm{Fe}_{3}-\mu_{3}-\mathrm{O}$ bonds are $1.86 \AA$ and the other is $2.07 \AA$, has very similar quadrupole splittings. ${ }^{52}$ In contrast, the roomtemperature Mössbauer spectrum for C2 (Figure 6) features a

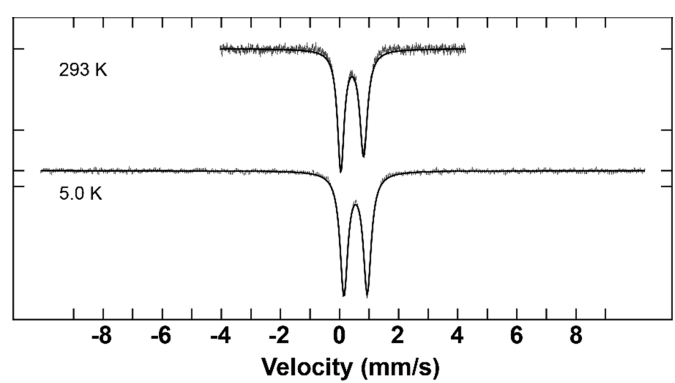

Figure 6. ${ }^{57} \mathrm{Fe}$ Mössbauer spectra of complex $\mathbf{C 2}$ at high and low temperatures, overlaid with corresponding fits using the parameters given in Table 3 at high temperature.

single, albeit slightly asymmetric, quadrupole doublet with a value approximately intermediate between those observed for $\mathrm{C1}$ at room temperature, consistent with the symmetrical $\mathrm{Fe}_{3}-\mu_{3}-\mathrm{O} \cdots \mathrm{H} \cdots \mu_{3}-\mathrm{O}-\mathrm{Fe}_{3}$ species inferred crystallographically. ${ }^{53}$ At low temperature, the Mössbauer spectrum for C2 is a single symmetrical doublet with a slightly larger isomer shift but essentially unchanged quadrupole splitting. However, for $\mathbf{C 1}$, the pair of quadrupole doublets appears to have collapsed into a single symmetrical quadrupole doublet, with a quadrupole splitting of $1.2 \mathrm{~mm} / \mathrm{s}$ and a slightly larger isomer shift of $0.51 \mathrm{~mm} / \mathrm{s}$. Tentatively, this might be ascribed to a phase transition (occurring below the structure-determination temperature) that leads to a symmetric $\mathrm{Fe}_{3}-\mu_{3}-\mathrm{O} \cdots \mathrm{H} \cdots \mu_{3}-\mathrm{O}-$ $\mathrm{Fe}_{3}$ moiety and a compressed and more strongly axial phenolato $\mathrm{O}-\mathrm{Fe}-\mu_{3}-\mathrm{O}$ group. However, the fit is poor, given the pronounced asymmetry of each peak in the doublet; moreover, the isomer shift with temperature is less than expected and the quadrupole splitting is more consistent with an $\left[\mathrm{Fe}_{3}-\mu_{3} \mathrm{O}\right]$ than with an $\left[\mathrm{Fe}_{3}-\mu_{3}-\mathrm{O} \cdots \mathrm{H} \cdots \mu_{3}-\mathrm{O}-\mathrm{Fe}_{3}\right]$ species (see above for C1). A much better fit is obtained with a pair of equal area quadrupole doublets, respectively, with the isomer shifts of 0.57 and $0.55 \mathrm{~mm} / \mathrm{s}$, quadrupole splittings of 1.22 and $0.82 \mathrm{~mm} / \mathrm{s}$, and peak widths of 0.28 and $0.44 \mathrm{~mm} / \mathrm{s}$.

Magnetic Measurements and Discussion. Magnetic susceptibility data for $\mathbf{C} \mathbf{1}$ and $\mathbf{C 2}$ were collected in the $T=$ $300-5 \mathrm{~K}$ range, in an applied field $B=0.1 \mathrm{~T}$, and are as plotted as the $\chi_{\mathrm{M}} T$ product versus $T$ in Figure 7 , where $\chi_{\mathrm{M}}$ is the molar magnetic susceptibility. In both cases, the $T=300 \mathrm{~K}$ value of $\chi_{\mathrm{M}} T\left(\mathbf{C 1}, 6.53 \mathrm{~cm}^{3} \mathrm{~K} / \mathrm{mol}\right.$; C2, $\left.8.39 \mathrm{~cm}^{3} \cdot \mathrm{K} / \mathrm{mol}\right)$ is well below the Curie constant expected for six noninteracting $\mathrm{Fe}(\mathrm{III})$ ions $\left(26.25 \mathrm{~cm}^{3} \mathrm{~K} / \mathrm{mol}\right)$. As the temperature is decreased, the value of $\chi_{\mathrm{M}} T$ decreases monotonically, reaching values close to zero in each case. This behavior is clearly indicative of strong antiferromagnetic exchange interactions between the $\mathrm{Fe}$ (III) ions, resulting in diamagnetic ground states for both $\mathbf{C l}$ and C2 (Figure 8).

Inspection of the molecular structures of $\mathbf{C} 1$ and $\mathbf{C} 2$ reveals that in each case the upper and lower $\left[\mathrm{Fe}_{3}\right]$ triangles are scalene in nature, with three different $\mathrm{Fe}-\mathrm{O}-\mathrm{Fe}$ and $\mathrm{Fe}-\mathrm{O}-$ $\mathrm{N}-\mathrm{Fe}$ angles. In addition, $\mathrm{C1} / \mathrm{C} 2$ display three/six different $\mathrm{Fe}-\mathrm{F}-\mathrm{Fe}$ angles between triangles, potentially resulting in a total of $6 / 12$ different exchange interactions. Clearly, this would lead to overparameterization, and so for simplicity, we used two models to fit the magnetic susceptibility data: (a) a $2 J$ model assuming a single interaction within an equilateral $\left[\mathrm{Fe}_{3}\right]$ triangle mediated by the oxide and oxime moieties $\left(J_{1}\right)$ and a single interaction between the triangles mediated by the fluoride ions $\left(J_{3}\right)$; (b) a $3 J$ model assuming an isosceles $\left[\mathrm{Fe}_{3}\right]$ triangle $\left(J_{1}, J_{2}\right)$ and a single interaction $\left(J_{3}\right)$ between the triangles. The latter model is a better representation of the structure when considering the $\mathrm{Fe}-\mathrm{O}-\mathrm{N}-\mathrm{Fe}$ torsion angles in $\mathbf{C 1}$ and $\mathbf{C 2}$, which are grouped into two distinct regions (C1:
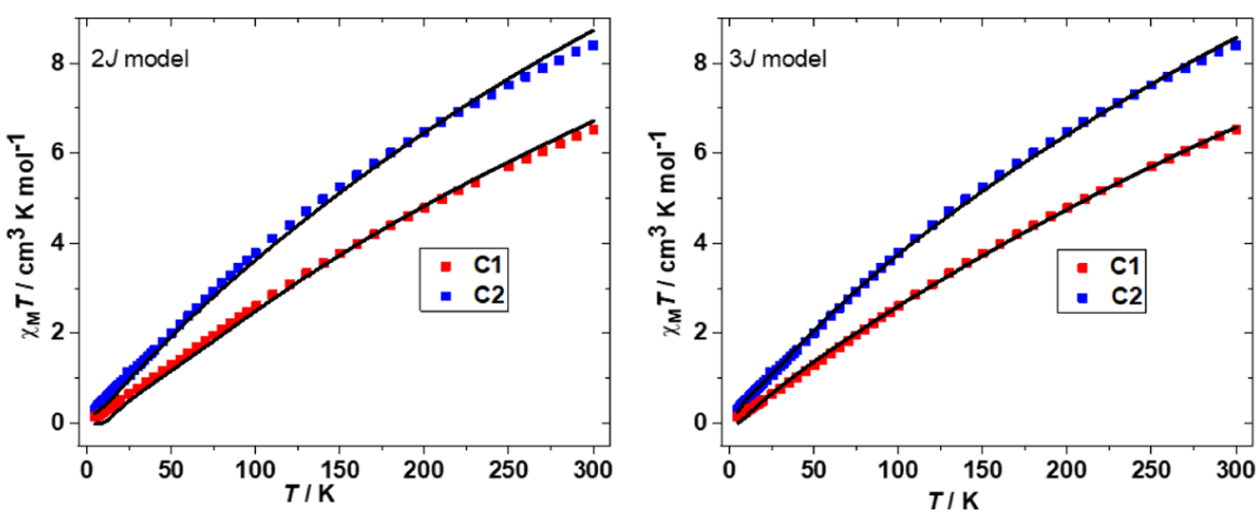

Figure 7. Plot of the magnetic susceptibility, as the product $\chi_{\mathrm{M}} T$ versus $T$ for $\mathbf{C} 1$ (red squares) and $\mathbf{C} 2$ (blue squares) measured in the $300-5 \mathrm{~K}$ temperature range in an applied field, $B=0.1 \mathrm{~T}$. The solid black lines are fits of the experimental data to spin-Hamiltonian eq 1 using the exchange coupling scheme shown in Figure 8. The plot on the left is that obtained from a $2 J$ model $\left(J_{1}=J_{2}\right)$, and the plot on the right is that obtained using a $3 J$ model. 


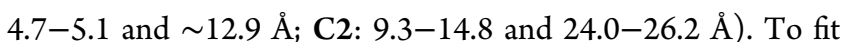
the susceptibility data, we employed spin-Hamiltonian eq 1

1: Generalized spin-Hamiltonian used to fit the $\chi_{\mathrm{M}} T$ versus $T$ data

$$
\hat{H}=\mu_{\mathrm{B}} B \sum_{i} g_{i} \hat{S}_{i}-2 \sum_{i, j<i} J_{i j} \hat{S}_{i} \hat{S}_{j}
$$

where the indices $i$ and $j$ refer to the $\mathrm{Fe}(\mathrm{III})$ ions, $\mu_{\mathrm{B}}$ is the Bohr magneton, $B$ is the applied magnetic field, $g$ is the $g$-factor of the $\mathrm{Fe}(\mathrm{III})$ ions (fixed at $g=2.00$ ), $\hat{S}$ is a spin operator, and $J$ is the isotropic exchange interaction.

For the $2 J$ model (Figure 7, left), this afforded the best-fit parameters: $J_{1}=-29.77( \pm 0.32) \mathrm{cm}^{-1}, J_{3}=-10.10( \pm 0.64)$ $\mathrm{cm}^{-1}$ (C1); $J_{1}=-10.00( \pm 0.001) \mathrm{cm}^{-1}, J_{3}=-0.08( \pm 0.26)$ $\mathrm{cm}^{-1}$ (C2). For the $3 J$ model (Figure 7 , right), this afforded the best-fit parameters: $J_{1}=-27.67( \pm 0.09) \mathrm{cm}^{-1}, J_{2}=$ $-35.22( \pm 0.11) \mathrm{cm}^{-1}, J_{3}=-8.47( \pm 0.09) \mathrm{cm}^{-1}(\mathrm{C1}) ; J_{1}=$ $-20.12( \pm 0.05) \mathrm{cm}^{-1}, J_{2}=-26.15( \pm 0.07) \mathrm{cm}^{-1}, J_{3}=-3.98$ $( \pm 0.05) \mathrm{cm}^{-1}(\mathbf{C 2})$. The $3 J$ model provides a superior fit, with better agreement between the two complexes. The stronger antiferromagnetic coupling for $\mathbf{C} \mathbf{1}$ compared to that for $\mathbf{C} 2$ apparent in Figure 7 and in the derived $J_{1}$ and $J_{2}$ values can be tied to the short $\mathrm{Fe}-\mu_{3}-\mathrm{O}$ distances observed for $\mathbf{C 1}$.

2: Isotropic spin-Hamiltonian used to fit the $\chi_{M} T$ versus $T$ data

$$
\begin{aligned}
& \hat{H}=-2 J_{1}\left(\hat{S}_{1} \cdot \hat{S}_{2}+\hat{S}_{4} \cdot \hat{S}_{5}\right) \\
& -2 J_{2}\left(\hat{S}_{2} \cdot \hat{S}_{3}+\hat{S}_{1} \cdot \hat{S}_{3}+\hat{S}_{4} \cdot \hat{S}_{6}+\hat{S}_{5} \cdot \hat{S}_{6}\right) \\
& -2 J_{3}\left(\hat{S}_{1} \cdot \hat{S}_{4}+\hat{S}_{1} \cdot \hat{S}_{6}+\hat{S}_{2} \cdot \hat{S}_{4}+\hat{S}_{2} \cdot \hat{S}_{5}+\hat{S}_{3} \cdot \hat{S}_{5}+\hat{S}_{3} \cdot \hat{S}_{6}\right)
\end{aligned}
$$

The values obtained are similar to those observed for structurally similar Fe(III) cages bridged by a combination of oxo, hydroxo, and oxime ligands. ${ }^{39,54,55}$ Indeed, both the magnitude and trend of the exchange interactions observed here are very similar to those obtained for the structurally similar complex $\left[\mathrm{Fe}_{6}{ }^{\mathrm{III}} \mathrm{O}(\mathrm{OH})_{7}\left(\mathrm{H}_{4} \mathbf{L}-2 \mathrm{H}\right)_{3}\right]\left(\mathrm{BF}_{4}\right)_{3} \quad\left(\mathrm{H}_{4} \mathbf{L}=\right.$ $3,3^{\prime}$ - $\left[N, N^{\prime}\right.$-dimethyl-1,8-octanediaminobis(methylene) $]$ bis [2hydroxy-5-tert-butylbenzaldehyde oxime]), ${ }^{39}$ in which the $\left[\mathrm{Fe}_{3}\right]$ triangles are linked by six hydroxide ions $\left(J_{1}=-21.5\right.$ $\mathrm{cm}^{-1}, J_{2}=-28.0 \mathrm{~cm}^{-1}, J_{3}=-0.3 \mathrm{~cm}^{-1}$ ). They are also in agreement with the magnetostructural model developed for $\mathrm{Fe}$ (III) cages by Cañada-Vilalta and co-workers. ${ }^{56}$ There are no reported magnetostructural correlations for the $\mathrm{Fe}(\mathrm{III})-\mathrm{F}-$ $\mathrm{Fe}(\mathrm{III})$ moiety, and of the few examples that exist in the literature, all are characterized by very small exchange interactions, as seen here. ${ }^{57}$

\section{CONCLUSIONS}

Complexes $\mathbf{C} 1$ and $\mathbf{C 2}$ contain the common metallic core, $\left[\mathrm{Fe}_{6}\left(\mathrm{OH}_{0.5}\right)_{2}\right]^{15+}$, but in distinctly different configurations at temperatures above $\sim 150 \mathrm{~K}$, as evidenced by Mössbauer spectroscopy. C1 consists of two crystallographically independent half-units from which the full clusters are generated by inversion symmetry. At temperatures above $\sim 150 \mathrm{~K}$, the proton between the two $\mathrm{Fe}_{3} \mathrm{O}$ clusters is asymmetrically located, $\mathrm{Fe}_{3}-\mu_{3}-\mathrm{OH} \cdots \mu_{3}-\mathrm{O}-\mathrm{Fe}_{3}$, giving rise to strong antiferromagnetic coupling and large quadrupole splitting in the Mössbauer spectrum. On the other hand, for $\mathbf{C 2}$, where the asymmetric unit comprises the full hexa-iron cluster, the proton is symmetrically located, $\mathrm{Fe}_{3}-\mu_{3}-\mathrm{O} \cdots \mathrm{H} \cdots \mu_{3}-\mathrm{O}-\mathrm{Fe}_{3}$. In all other respects, these two complexes are structurally very

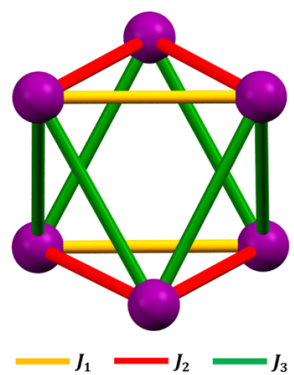

Figure 8. Exchange interaction scheme used to fit the susceptibility data for $\mathbf{C 1}$ and $\mathbf{C 2}$. The model depicted assumes two different coupling constants within each $\left[\mathrm{Fe}_{3}\right]$ triangle $\left(J_{1}\right.$ and $\left.J_{2}\right)$ and a single coupling constant between triangles $\left(J_{3}\right)$. For the $2 J$ model discussed in the text, $J_{1}=J_{2}$.

similar. The magnetic susceptibility analyses for these complexes indicate the presence of strong antiferromagnetic exchange interactions between the metal centers.

Although the Mössbauer data of $\mathbf{C l}$ at low temperatures $(\sim 80 \mathrm{~K})$ can be interpreted in terms of a structural phase transition occurring that leads to a more symmetrical $\mathrm{Fe}_{3}-\mu_{3}-$ $\mathrm{OHO}-\mu_{3}-\mathrm{Fe}_{3}$ moiety, the magnetic susceptibility data are well fit by the $3 J$ model over the entire temperature range and the Mössbauer data are much better fit by two quadrupole doublets, the larger characteristic of an $\mathrm{Fe}-\mu_{3}-\mathrm{O}$ species and the smaller characteristic of an $\mathrm{Fe}-\mu_{3} \mathrm{OH}$ species. On the other hand, $\mathbf{C 2}$ remains symmetrical at all temperatures. While not conclusive, an explanation for such behavior may lie in the ligands that stabilize each hexa-iron cluster. In C2, the iron triads are linked not only by the $\mu_{2}-\mathrm{F}$ bridged but also by the ligand backbone, which clearly places additional constraints on conformational flexibility leading to the close $\mu_{3}-\mathrm{O} \cdots(\mathrm{H}) \cdots \mathrm{O}$ $\mu_{3}$ interaction, aided by the staggered arrangement of the triiron planes. Greater conformational flexibility is, however, present in $\mathbf{C 1}$, where the iron triads are noticeably closer than for C2 (and also for complexes $\mathbf{2 - 5}$ in Table 2) and the Fe$\mathrm{F}-\mathrm{Fe}$ angles are noticeably more acute but the displacements of the $\mu_{3}-\mathrm{O}$ moieties from the plane of the $\mathrm{Fe}_{3}$ triangles are substantially less.

\section{ASSOCIATED CONTENT}

\section{Supporting Information}

The Supporting Information is available free of charge at https://pubs.acs.org/doi/10.1021/acsomega.1c02255.

CCDC 2048582 (C1) (CIF)

CCDC 2048583 (C2) (CIF)

\section{AUTHOR INFORMATION}

\section{Corresponding Author}

Paul G. Plieger - School of Fundamental Sciences, Massey University, Palmerston North 4410, New Zealand; ○ orcid.org/0000-0003-4886-7677; Email: p.g.plieger@ massey.ac.nz.

\section{Authors}

D. Nirosha T. De Silva - School of Fundamental Sciences, Massey University, Palmerston North 4410, New Zealand

Tyson N. Dais - School of Fundamental Sciences, Massey University, Palmerston North 4410, New Zealand

Geoffrey B. Jameson - School of Fundamental Sciences, Massey University, Palmerston North 4410, New Zealand; (1) orcid.org/0000-0003-4839-0784 
Daniel J. Cutler - EaStCHEM School of Chemistry, The University of Edinburgh, Edinburgh EH9 3FJ, U.K.

Euan K. Brechin - EaStCHEM School of Chemistry, The University of Edinburgh, Edinburgh EH9 3FJ, U.K.

Casey G. Davies - Department of Chemistry \& MacDiarmid Institute for Advanced Materials \& Nanotechnology, University of Otago, Dunedin 9016, New Zealand

Guy N. L. Jameson - School of Chemistry and Bio21 Molecular Science and Biotechnology Institute, The University of Melbourne, Parkville, Victoria 3052, Australia; () orcid.org/0000-0001-9416-699X

Complete contact information is available at: https://pubs.acs.org/10.1021/acsomega.1c02255

\section{Notes}

The authors declare no competing financial interest.

The data can be obtained free of charge via www.ccdc.cam.ac.uk/data_request/cif or by emailing data \_request@ccdc.cam.ac.uk, or by contacting The Cambridge Crystallographic Data center, 12 Union Road, Cambridge CB2 1EZ, U.K.; Fax: +441223336033.

\section{ACKNOWLEDGMENTS}

T.N.D. and P.G.P. thank Massey University for the award of a Massey University Doctoral Scholarship for Maori to T.N.D.

\section{REFERENCES}

(1) Chaudhuri, P. Homo- and hetero-polymetallic exchange coupled metal-oximates. Coord. Chem. Rev. 2003, 243, 143-190.

(2) Raptopoulou, C. P.; Sanakis, Y.; Boudalis, A. K.; Psycharis, V. Salicylaldoxime $\left(\mathrm{H}_{2}\right.$ salox $)$ in iron(III) carboxylate chemistry: Synthesis, X-ray crystal structure, spectroscopic characterization and magnetic behavior of trinuclear oxo-centered complexes. Polyhedron 2005, 24, 711-721.

(3) Chaudhuri, P.; Winter, M.; Fleischhauer, P.; Haase, W.; Floerke, U.; Haupt, H.-J. Synthesis, structure and magnetism of a tetranuclear $\mathrm{Fe}(\mathrm{III})$ complex containing an $\left[\mathrm{Fe}_{4}\left(\mu_{3}-\mathrm{O}\right)_{2}\right]^{8+}$ core. Inorg. Chim. Acta 1993, 212, 241-249.

(4) Verani, C. N.; Bothe, E.; Burdinski, D.; Weyhermuller, T.; Florke, U.; Chaudhuri, P. Synthesis, structure, electrochemistry, and magnetism of $\left[\mathrm{Mn}^{\mathrm{III}} \mathrm{Mn}^{\mathrm{III}}\right],\left[\mathrm{Mn}^{\mathrm{III}} \mathrm{Fe}^{\mathrm{III}}\right]$ and $\left[\mathrm{Fe}^{\mathrm{III}} \mathrm{Fe}^{\mathrm{III}}\right]$ cores: Generation of phenoxyl radical containing $\left[\mathrm{Fe}^{\mathrm{III}} \mathrm{Fe}^{\mathrm{III}}\right]$ species. Eur. J. Inorg. Chem. 2001, 2161-2169.

(5) Liu, S.; Zhu, H.; Zubieta, J. Reactions of polyoxomolybdates with oximes. The crystal and molecular structures of $\left[\left(\mathrm{C}_{4} \mathrm{H}_{9}\right)_{4} \mathrm{~N}\right]_{2}\left[\mathrm{Mo}_{2} \mathrm{O}_{5}\left(\mathrm{C}_{6} \mathrm{H}_{4}(\mathrm{O}) \mathrm{CHNO}\right)_{2}\right] \cdot \mathrm{CH}_{2} \mathrm{Cl}_{2}$ and $\left[\left(\mathrm{C}_{4} \mathrm{H}_{9}\right)_{4} \mathrm{~N}\right]_{2}\left[\mathrm{Mo}_{2} \mathrm{O}_{4}\left(\mathrm{C}_{6} \mathrm{H}_{5} \mathrm{CH}(\mathrm{O}) \mathrm{C}(\mathrm{NO}) \mathrm{C}_{6} \mathrm{H}_{4}\right)_{2}\right]$. Polyhedron 1989, 8, 2473-2480.

(6) Chaudhuri, P.; Hess, M.; Weyhermuller, T.; Bill, E.; Haupt, H.J.; Florke, U. A novel series of asymmetric trinuclear $\mathrm{M}(\mathrm{III})$ complexes $(\mathrm{M}=\mathrm{Ti}, \mathrm{V}, \mathrm{Cr}, \mathrm{Mn}, \mathrm{Fe}, \mathrm{Co})$ with the $\left[\mathrm{M}_{3} \mathrm{O}_{2}\right]^{6+}$ core by a deoximation reaction exemplified by the $\mathrm{V}$ (III) complex. Inorg. Chem. Commun. 1998, 1, 39-42.

(7) Bill, E.; Krebs, C.; Winter, M.; Gerdan, M.; Trautwein, A. X.; Floerke, U.; Haupt, H.-J.; Chaudhuri, P. A triangular iron(III) complex potentially relevant to iron(III)-binding sites in ferreascidin. Chem. - Eur. J. 1997, 3, 193-201.

(8) Chaudhuri, P.; Rentschler, E.; Birkelbach, F.; Krebs, C.; Bill, E.; Weyhermuller, T.; Florke, U. Ground spin state variation in carboxylate-bridged tetranuclear $\left[\mathrm{Fe}_{2} \mathrm{Mn}_{2} \mathrm{O}_{2}\right]^{8+}$ cores and a comparison with their $\left[\mathrm{Fe}_{4} \mathrm{O}_{2}\right]^{8+}$ and $\left[\mathrm{Mn}_{4} \mathrm{O}_{2}\right]^{8+}$ congeners. Eur. J. Inorg. Chem. 2003, 2003, 541-555.

(9) Chaudhuri, P.; Birkelbach, F.; Winter, M.; Staemmler, V.; Fleischhauer, P.; Haase, W.; Florke, U.; Haupt, H.-J. A novel tetranuclear $\left[\mathrm{Cr}_{2}{ }^{\mathrm{III}} \mathrm{Mn}_{2}{ }^{\mathrm{III}}\left(\mu_{3}-\mathrm{O}\right)_{2}\right]^{8+}$ core with an $\mathrm{S}_{\mathrm{T}}=0$ spin ground state. J. Chem. Soc., Dalton Trans. 1994, 2313-2319.
(10) Murray, K. S. Binuclear oxo-bridged iron(III) complexes. Coord. Chem. Rev. 1974, 12, 1-35.

(11) Shiemke, A. K.; Loehr, T. M.; Sanders-Loehr, J. Resonance Raman study of oxyhemerythrin and hydroxomethemerythrin. Evidence for hydrogen bonding of ligands to the iron-oxygen-iron center. J. Am. Chem. Soc. 1986, 108, 2437-2443.

(12) Doi, K.; Antanaitis, B. C.; Aisen, P. The Binuclear Iron Centers of Uteroferrin and the Purple Acid Phosphatases. In Structure Bonding; Springer, 1988; Vol. 70, pp 1-26.

(13) Que, L., Jr.; True, A. E. Dinuclear iron- and manganese-oxo sites in biology. Prog. Inorg. Chem. 1990, 38, 97-200.

(14) Vincent, J. B.; Olivier-Lilley, G. L.; Averill, B. A. Proteins containing oxo-bridged dinuclear iron centers: a bioinorganic perspective. Chem. Rev. 1990, 90, 1447-1467.

(15) Kurtz, D. M. Oxo-and hydroxo-bridged diiron complexes: a chemical perspective on a biological unit. Chem. Rev. 1990, 90, 585606.

(16) Nordlund, P.; Sjoeberg, B. M.; Eklund, H. Three-dimensional structure of the free radical protein of ribonucleotide reductase. Nature 1990, 345, 593-598.

(17) Holmes, M. A.; Le Trong, I.; Turley, S.; Sieker, L. C.; Stenkamp, R. E. Structures of deoxy and oxy hemerythrin at $2.0 \AA$ resolution. J. Mol. Biol. 1991, 218, 583-593.

(18) Wilkins, R. G. Binuclear iron centers in proteins. Chem. Soc. Rev. 1992, 21, 171-178.

(19) Solomon, E. I.; Zhang, Y. The electronic structures of active sites in non-heme iron enzymes. Acc. Chem. Res. 1992, 25, 343-352.

(20) Theil, E. C. Ferritin: Structure, gene regulation, and cellular function in animals, plants, and microorganisms. Annu. Rev. Biochem. 1987, 56, 289-315.

(21) Harrison, P. M.; Andrews, S. C.; Artymiuk, P. J.; Ford, G. C.; Guest, J. R.; Hirzmann, J.; Lawson, D. M.; Livingstone, J. C.; Smith, J. M. A.; Treffry, A.; Yewdall, S. J. Probing structure-function relations in ferritin and bacterioferritin. Adv. Inorg. Chem. 1991, 36, 449-486.

(22) Flamourakis, A. G.; Kalofolias, D. A.; Siczek, M.; Lis, T.; Brechin, E. K.; Milios, C. J. New members of the $\left[\mathrm{Mn}_{6} /\right.$ oxime $]$ family and analogues with converging $\left[\mathrm{Mn}_{3}\right]$ planes. J. Coord. Chem. 2016, 69, 826-840.

(23) Inglis, R.; Taylor, S. M.; Jones, L. F.; Papaefstathiou, G. S.; Perlepes, S. P.; Datta, S.; Hill, S.; Wernsdorfer, W.; Brechin, E. K. Twisting, bending, stretching: Strategies for making ferromagnetic $\left[\mathrm{Mn}_{3}{ }^{\mathrm{III}}\right]$ triangles. Dalton Trans. 2009, 42, 9157-9168.

(24) Martínez-Lillo, J.; Tomsa, A.-R.; Li, Y.; Chamoreau, L.-M.; Cremades, E.; Ruiz, E.; Barra, A.-L.; Proust, A.; Verdaguer, M.; Gouzerh, P. Synthesis, crystal structure and magnetism of new salicylamidoxime-based hexanuclear manganese(III) single-molecule magnets. Dalton Trans. 2012, 41, 13668-13681.

(25) Milios, C. J.; Inglis, R.; Vinslava, A.; Bagai, R.; Wernsdorfer, W.; Parsons, S.; Perlepes, S. P.; Christou, G.; Brechin, E. K. Toward a magnetostructural correlation for a family of $\mathrm{Mn}^{6} \mathrm{SMMs}$. J. Am. Chem. Soc. 2007, 129, 12505-12511.

(26) Milios, C. J.; Raptopoulou, C. P.; Terzis, A.; Lloret, F.; Vicente, R.; Perlepes, S. P.; Escuer, A. Hexanuclear manganese(III) singlemolecule magnets. Angew. Chem., Int. Ed. 2004, 43, 210-212.

(27) Milios, C. J.; Vinslava, A.; Wernsdorfer, W.; Prescimone, A.; Wood, P. A.; Parsons, S.; Perlepes, S. P.; Christou, G.; Brechin, E. K. Spin switching via targeted structural distortion. J. Am. Chem. Soc. 2007, 129, 6547-6561.

(28) Milios, C. J.; Piligkos, S.; Brechin, E. K. Ground state spinswitching via targeted structural distortion: Twisted single-molecule magnets from derivatised salicylaldoximes. Dalton Trans. 2008, 18091817.

(29) Inglis, R.; Milios, C. J.; Jones, L. F.; Piligkos, S.; Brechin, E. K. Twisted molecular magnets. Chem. Commun. 2012, 48, 181-190.

(30) Tomsa, A.-R.; Martinez-Lillo, J.; Li, Y.; Chamoreau, L.-M.; Boubekeur, K.; Farias, F.; Novak, M. A.; Cremades, E.; Ruiz, E.; Proust, A.; Verdaguer, M.; Gouzerh, P. A new family of oxime-based hexanuclear manganese(III) single molecule magnets with high anisotropy energy barriers. Chem. Commun. 2010, 46, 5106-5108. 
(31) Chang, J. Y. C.; Parsons, S.; Plieger, P. G.; Tasker, P. A. Anionselective receptors based on dinuclear copper(II) and nickel(II) cage complexes of bis-salicylaldimines. J. Inclusion Phenom. Macrocyclic Chem. 2011, 71, 529-536.

(32) Wenzel, M.; Bruere, S. R.; Knapp, Q. W.; Tasker, P. A.; Plieger, P. G. Zwitterionic dicopper helicates: Anion encapsulation and binding studies. Dalton Trans. 2010, 39, 2936-2941.

(33) Wenzel, M.; Jameson, G. B.; Ferguson, L. A.; Knapp, Q. W.; Forgan, R. S.; White, F. J.; Parsons, S.; Tasker, P. A.; Plieger, P. G. Anion-induced contraction of helical receptors. Chem. Commun. 2009, 3606-3608.

(34) Wenzel, M.; Knapp, Q. W.; Plieger, P. G. A bissalicylaldoximato-copper(II) receptor for selective sulfate uptake. Chem. Commun. 2011, 47, 499-501.

(35) Plieger, P. G.; Parsons, S.; Parkin, A.; Tasker, P. A. Transport of metal salts; encapsulation of anions in dinuclear $\mathrm{Cu}$ (II) complexes, where $\mathrm{L}=2,2^{\prime}$-[1,6-hexanediylbis[(methylimino)methylene $]$ bis[4tert-butyl-6-(phenylazomethinyl)phenol]. J. Chem. Soc., Dalton Trans. 2002, 3928-3930.

(36) De Silva, D. N. T.; Jameson, G. B.; Pannu, A. P. S.; Pouhet, R.; Wenzel, M.; Plieger, P. G. Piperazine linked salicylaldoxime and salicylaldimine-based dicopper(II) receptors for anions. Dalton Trans. 2015, 44, 15949-15959.

(37) Woodhouse, S. S.; De Silva, D. N. T.; Jameson, G. B.; Cutler, D. J.; Sanz, S.; Brechin, E. K.; Davies, C. G.; Jameson, G. N. L.; Plieger, P. G. New salicylaldoximato-borate ligands resulting from anion hydrolysis and their respective copper and iron complexes. Dalton Trans. 2019, 48, 11872-11881.

(38) Wenzel, M.; Forgan, R. S.; Faure, A.; Mason, K.; Tasker, P. A.; Piligkos, S.; Brechin, E. K.; Plieger, P. G. A new polynuclear coordination type for (salicylaldoxime)copper(II) complexes: Structure and magnetic properties of an (oxime) $\mathrm{Cu}_{6}$ cluster. Eur. J. Inorg. Chem. 2009, 2009, 4613-4617.

(39) Mason, K.; Chang, J.; Prescimone, A.; Garlatti, E.; Carretta, S.; Tasker, P. A.; Brechin, E. K. Linking $\left[\mathrm{M}_{3}{ }^{\mathrm{III}}\right]$ triangles with "doubleheaded" phenolic oximes. Dalton Trans. 2012, 41, 8777-8785.

(40) Mason, K.; Gass, I. A.; Parsons, S.; Collins, A.; White, F. J.; Slawin, A. M. Z.; Brechin, E. K.; Tasker, P. A. Building Fe(III) clusters with derivatised salicylaldoximes. Dalton Trans. 2010, 39, 2727-2734.

(41) Hołyńska, M.; Clerac, R.; Langer, T.; Poettgen, R.; Dehnen, S. Selective syntheses, structures and magnetic properties of $\mathrm{Fe}(\mathrm{III})$ complexes of different nuclearities. Polyhedron 2013, 52, 1425-1430. (42) Aldred, R.; Johnston, R.; Levin, D.; Neilan, J. Magnesiummediated ortho-specific formylation and formaldoximation of phenols. J. Chem. Soc., Perkin Trans. 1 1994, 1, 1823-1831.

(43) Wang, Q.; Wilson, C.; Blake, A. J.; Collinson, S. R.; Tasker, P. A.; Schroeder, M. The one-pot halomethylation of 5-substituted salicylaldehydes as convenient precursors for the preparation of heteroditopic ligands for the binding of metal salts. Tetrahedron Lett. 2006, 47, 8983-8987.

(44) Stevens, J. R.; Plieger, P. G. Anion-driven conformation control and enhanced sulfate binding utilising aryl linked salicylaldoxime dicopper helicates. Dalton Trans. 2011, 40, 12235-12241.

(45) Sheldrick, G. M. Crystal structure refinement with SHELXL. Acta Crystallogr., Sect. C: Struct. Chem. 2015, 71, 3-8.

(46) Sheldrick, G. M. Acta Crystallogr., Sect. A: Found. Crystallogr. 2008, 64, 112.

(47) Dolomanov, O. V.; Bourhis, L. J.; Gildea, R. J.; Howard, J. A.; Puschmann, H. OLEX2: A complete structure solution, refinement and analysis program. J. Appl. Crystallogr. 2009, 42, 339-341.

(48) Boudreaux, E. A.; Mulay, L. N. Theory and Applications of Molecular Paramagnetism; Wiley-Interscience, 1976; pp 512.

(49) Steiner, T. Reviews: The hydrogen bond in the solid state. Angew. Chem., Int. Ed. 2002, 41, 48-76.

(50) Gorinchoy, V. V.; Zubareva, V. E.; Shova, S. G.; Szafranski, V. N.; Lipkowski, J.; Stanica, N.; Simonov, Y. A.; Turta, C. I. Homo- and heteronuclear iron complexes $\mathrm{Fe}_{2} \mathrm{MO}$ with salicylic acid: Synthesis, structures, and physicochemical properties. Russ. J. Coord. Chem. 2009, 35, 731-739.
(51) Moessbauer Spectroscopy of Environmental Materials and Their Industrial Utilization,Murad, E.; Cashion, J., Eds.; Kluwer Academic, 2004; p 440.

(52) Gorun, S. M.; Papaefthymiou, G. C.; Frankel, R. B.; Lippard, S. J. Synthesis, structure, and magnetic and Mössbauer properties of mononuclear and asymmetric, oxo-bridged trinuclear iron(III) complexes of a new polyimidazole ligand. J. Am. Chem. Soc. 1987, 109, 4244-4255.

(53) Siddiqi, Z. A.; Shahid, M.; Khalid, M.; Noor, S.; Kumar, S. Synthesis, physico-chemical and spectral investigations of novel homo-bimetallic mixed-ligand complexes: ${ }^{57} \mathrm{Fe}$ Mössbauer parameters of $\left[\mathrm{Fe}_{2}(\mathrm{imda})_{2}\left(\mathrm{H}_{2} \mathrm{O}\right)_{3} \mathrm{Cl}\right]$. Spectrochim. Acta, Part A 2010, 75, 61-68.

(54) Gass, I. A.; Milios, C. J.; Collins, A.; White, F. J.; Budd, L.; Parsons, S.; Murrie, M.; Perlepes, S. P.; Brechin, E. K. Polymetallic clusters of iron(III) with derivatized salicylaldoximes. Dalton Trans. 2008, 2043-2053.

(55) Mason, K.; Gass, I. A.; White, F. J.; Papaefstathiou, G. S.; Brechin, E. K.; Tasker, P. A. Hexa- and octanuclear iron(III) salicylaldoxime clusters. Dalton Trans. 2011, 40, 2875-2881.

(56) Cañada-Vilalta, C.; O’Brien, T. A.; Brechin, E. K.; Pink, M.; Davidson, E. R.; Christou, G. Large spin differences in structurally related $\mathrm{Fe}_{6}$ molecular clusters and their magnetostructural explanation. Inorg. Chem. 2004, 43, 5505-5521.

(57) Bazán, B.; Mesa, J. L.; Pizarro, J. L.; Goñi, A.; Lezama, L.; Arriortua, M. I.; Rojo, T. A new three-dimensional inorganic-organic hybrid fluorinated-iron(III) arsenate: $\left(\mathrm{C}_{6} \mathrm{H}_{14} \mathrm{~N}_{2}\right)$ $\left[\mathrm{Fe}_{3}\left(\mathrm{HAsO}_{4}\right)_{2}\left(\mathrm{AsO}_{4}\right) \mathrm{F}_{4}\right]_{0.5} \mathrm{H}_{2} \mathrm{O}$. Hydrothermal synthesis, crystal structure, and spectroscopic and magnetic properties. Inorg. Chem. 2001, 40, 5691-5694. 


\section{University Library}

\section{- M M I N E R VA \\ A gateway to Melbourne's research publications}

Minerva Access is the Institutional Repository of The University of Melbourne

Author/s:

De Silva, DNT;Dais, TN;Jameson, GB;Cutler, DJ;Brechin, EK;Davies, CG;Jameson, GNL;Plieger, PG

Title:

Synthesis and Characterization of Symmetrically versus Unsymmetrically Proton-Bridged Hexa-Iron Clusters

Date:

2021-06-15

Citation:

De Silva, D. N. T., Dais, T. N., Jameson, G. B., Cutler, D. J., Brechin, E. K., Davies, C. G., Jameson, G. N. L. \& Plieger, P. G. (2021). Synthesis and Characterization of Symmetrically versus Unsymmetrically Proton-Bridged Hexa-Iron Clusters. ACS OMEGA, 6 (25), pp.16661-16669. https://doi.org/10.1021/acsomega.1c02255.

Persistent Link:

http://hdl.handle.net/11343/281083

License:

CC BY-NC-ND 